\title{
Effect of operating parameters on production of bio-oil from fast pyrolysis of maize stalk in bubbling fluidized bed reactor
}

\author{
Najaf Ali ${ }^{*}$, Mahmood Saleem', Khurram Shahzad ${ }^{2}$, Sadiq Hussain ${ }^{3}$, Arshad Chughtai ${ }^{1,4}$ \\ ${ }^{1}$ University of the Punjab, Institute of Chemical Engineering \& Technology, Pakistan \\ ${ }^{2}$ University of the Punjab, Centre for Coal Technology, Pakistan \\ ${ }^{3}$ NFC Institute of Engineering \& Technology Multan, Pakistan \\ ${ }^{4}$ National University of Science and Technology Islamabad, School of Chemical and Materials Engineering, Pakistan \\ "Corresponding author: e-mail: najafawan@hotmail.com
}

\begin{abstract}
The yield and composition of pyrolysis products depend on the characteristics of feed stock and process operating parameters. Effect of particle size, reaction temperature and carrier gas flow rate on the yield of bio-oil from fast pyrolysis of Pakistani maize stalk was investigated. Pyrolysis experiments were performed at temperature range of $360-540^{\circ} \mathrm{C}$, feed particle size of $1-2 \mathrm{~mm}$ and carrier gas flow rate of $7.0-13.0 \mathrm{~m}^{3} / \mathrm{h}(0.6-1.1 \mathrm{~m} / \mathrm{s}$ superficial velocity). Bio-oil yield increased with the increase of temperature followed by a decreasing trend. The maximum yield of bio-oil obtained was $42 \mathrm{wt} \%$ at a temperature of $490^{\circ} \mathrm{C}$ with the particle size of around $1.0 \mathrm{~mm}$ and carrier gas flow rate of $11.0 \mathrm{~m}^{3} / \mathrm{h}(0.9 \mathrm{~m} / \mathrm{s}$ superficial velocity). High temperatures resulted in the higher ratios of char and non-condensable gas.
\end{abstract}

Keywords: fast pyrolysis, bio-oil, temperature, particle size, carrier gas flow rate, maize stalk.

\section{INTRODUCTION}

Pakistan is an agricultural country and produces around 69 million tons of field based crop residues annually, out of which 2.50 million tons is maize stalk. Maize stalk can be used for the production of renewable energy through pyrolysis process. Pyrolysis is a thermochemical conversion process used to convert biomass into liquid fuel ${ }^{1,2}$. It is thermal decomposition of biomass by heat in the absence of oxygen to yield liquid, solid and gaseous products $^{3,4}$. It is not possible to define pyrolysis specifically because in early times it named as carbonization in which primary product is charcoal. Today the term pyrolysis is understood for the process in which liquid fuel is the key product. In present energy development, pyrolysis process has attained distinct consideration because of biomass conversion into energy rich products. Pyrolysis is thought to be a promising route for conversion of biomass into bio-fuels and chemicals ${ }^{5-7}$. The basic reaction taking place during pyrolysis process is:

Biomass $\rightarrow$ Charcoal + Volatiles

The process of pyrolysis may be categorized as fast pyrolysis, conventional pyrolysis and flash pyrolysis ${ }^{\mathbf{8}, \boldsymbol{9}}$. Conventional pyrolysis may be known as slow pyrolysis or carbonization which takes place at reaction conditions of low temperature, slow heating rate and high vapor residence time. Charcoal is known as the principal product of this pyrolysis process. Fast pyrolysis process is conducted to yield liquid fuel at moderate reaction temperature and short vapor residence time whereas flash pyrolysis follows at high heating rate, very short vapor residence time of few seconds or less and very fine feed particle size $(\leq 2 \mathrm{~mm})^{10-12}$.

The yield and composition of bio-oil depend on the biomass feedstock and the operating conditions ${ }^{8,13-15}$. Reaction temperature, biomass feed size, residence time, heat transfer rate, flow rate of carrier gas, mineral matter and reactor types are the major parameters to consider for pyrolysis ${ }^{16-18}$. In pyrolysis, the biomass goes through primary and secondary reactions. The key components of biomass (cellulose, hemicellulose and lignin) decompose according to primary reactions resulting into primaryand intermediate products. The intermediate products further go through secondary reactions depending on the operating conditions and nature of the biomass ${ }^{19,20}$.

Reactor temperature is very important concerning the yield of pyrolysis products ${ }^{21}$. A temperature range of $450-550^{\circ} \mathrm{C}$ is reported for different biomasses ${ }^{22}$. In general the yield of bio-oil first increases reaches a maximum and then declines with increasing reactor temperature. The actual maxima are specific to the biomass, reactor type and design. The secondary vapor cracking reactions strongly affect the bio-oil yield ${ }^{23-26}$. The bio-char formation takes place at relatively low temperatures due to the lower heating rate and slow pyrolysis. Above $500^{\circ} \mathrm{C}$, yield of non-condensable gases increases with subsequent decrease in bio-oil yield ${ }^{23,27}$. The char yield decreases with the increase of temperature ${ }^{28}$. The char produced at higher temperature contains higher carbon content ${ }^{29}$. Lowering the reaction temperature $\left(<400^{\circ} \mathrm{C}\right)$ leads to formation of lower molecular weight liquids ${ }^{30}$. Different researchers investigated the effect of temperature on the yield of pyrolysis products for pine wood, miscanthus cassava rhizome (CR), cassava stalk (CS) and mallee bark $^{31-34}$.

Particle size of feedstock is important for fast pyrolysis process. The larger size of particles has tendency to give more char by controlling the release of primary pyrolysis vapors and increasing secondary char producing reactions ${ }^{35}$. Thus, for the production of char, large size biomass particles are required whereas in order to get maximum yield of bio-oil, small size particles are preferred. With the increase of particle sizes, bio-oil yield decreases and char yield increases as these particles heat up more slowly ${ }^{36}$. On the other hand, small particle size increases the gas yield as a result of greater heat transfer coefficient ${ }^{37}$. So distribution of the products strongly depends on the particle size, demanding a practically uniform temperature distribution inside the reactor. Moreover, biomass particle size is also reliant on the 
type of reactor used for fast pyrolysis. In continuous-feed fluidized bed reactors, small biomass particle sizes $(\leq 2 \mathrm{~mm})^{\mathbf{3}, \mathbf{2 2}}$ is agreed to achieve high heating rates. A small biomass particle size is required in order to get rapid heating and complete devolatilization in the pyrolysis process ${ }^{38,39}$. The effects of biomass particle sizes in fast pyrolysis can be compared only for similar types of biomasses having the same milling methods, shape and physical properties ${ }^{\mathbf{4 0}}$. Many tests have been carried out to investigate the effect of particle size on yields of pyrolysis oil, char and gas for aspen popular wood, jatropha oil cake, eucalyptus wood, Japanese larch and miscanthus ${ }^{32,41-44}$ in fluidized bed reactor. For these biomasses, with the increase of particle size, the bio-oil and char yield was reduced and gas yields increased. Some researchers studied the effect of particle size on the yield of pyrolysis products in modified forms of fluidized bed reactor ${ }^{45,}{ }^{46}$.

The carrier gas removes the pyrolysis products from hot zone to reduce the secondary cracking reactions ${ }^{47}$ for example thermal cracking, polymerization and condensation to maximize bio-oil yield. High flow rates of carrier gas allow short vapor residence time and vice versa. Short vapor residence time is a key factor to get the maximum bio-oil yields ${ }^{\mathbf{4 8 - 5 0}}$ and perfect quenching of pyrolysis vapors is required to restrict the secondary reactions ${ }^{\mathbf{5 1}}$. Vapor residence time is the available reaction time for secondary tar reactions in biomass pyrolysis which affects the yields of gaseous and liquid products. The recommended value of vapor residence time from the literature ${ }^{\mathbf{3 8}}$ for fast pyrolysis of biomass at a temperature of $500^{\circ} \mathrm{C}$ is $\leq 2$ seconds to attain the maximum bio-oil yield. Vapor residence time of a few hundred milliseconds is needed for the production of optimum yields of chemicals and food additives ${ }^{52}$. Longer vapor residence times in fast pyrolysis result in significant decrease in the yield of bio-oil due to secondary cracking reactions ${ }^{\mathbf{4}, 30}$. Park et al. ${ }^{53}$ investigated the influence of the nitrogen flow rate on the pyrolysis products distribution. By the decrease in gas flow rate, the oil yield was decreased, however yields of char and gas increased due to incomplete fluidization and chances of the happening of secondary vapor cracking reactions may be due to the longer vapor residence time. Heo et al. ${ }^{32}$ explained the effect of carrier gas flow on the yields of biomass pyrolysis products. Piskorz et al. ${ }^{24}$ described the effect of vapor residence time on pyrolysis of sorghum bagasse feedstock. Scott et al. ${ }^{54}$ investigated the effect of vapor residence time on the product yields of lignocellulosic wastes in a bench scale fluidized bed reactor. Heo et al. ${ }^{55}$ explained the effect of gas flow rate of nitrogen and pyrolysis gas on the product distribution of waste furniture saw dust in fluidized bed reactor. Raja et al. ${ }^{\mathbf{5 6}}$ investigated the flow rate of nitrogen gas from 1.25-2.4 $\mathrm{m}^{3} / \mathrm{h}$ for pyrolysis of pungam oil cake in electrically heated fluidized bed reactor. Sulaiman et al. ${ }^{57}$ studied the impact of key parameters to determine the maximum yield and quality of liquid fuel in bench scale fluidized bed reactor. The vapor residence time was set in the range of $0.79-1.32 \mathrm{~s}$ by the change of carrier gas flow rate. Mante et al. ${ }^{\mathbf{5 8}}$ investigated the parametric study on fast pyrolysis of manure and wood shavings in fluidized bed reactor. The experiments were conducted at nitrogen flow rates of $0.72-1.44 \mathrm{~m}^{3} / \mathrm{h}$. Tsai et al. ${ }^{59}$ discussed the effect of carrier gas flow on fast pyrolysis of rice husk.

Presently, there is no comprehensive research about the effect of temperature, feed particle size, carrier gas flow rate on pyrolysis of maize stalk in bubbling fluidized bed reactor. This study is carried out to determine the optimum temperature, feed particle size and carrier gas flow rate to obtain maximum yield of bio-oil and its characterization.

\section{EXPERIMENTAL PROCEDURES}

\section{Material and methods}

Maize stalk used as feedstock was collected from Pakpattan, District Sahiwal, Pakistan and shredded into coarse particles. The samples were finally ground in the grinding mill to the particle size of 1-2 $\mathrm{mm}$ and were air dried to decrease the moisture content. The feedstock was dried in an oven at $105^{\circ} \mathrm{C}$ for overnight to reduce the moisture less than $10 \mathrm{wt} \%$ prior to the pyrolysis experiments.

Ultimate analysis, proximate analysis and higher heating value (HHV) of the maize stalk was determined as per standard procedures using the standard analyzers (Vario Micro CHNS \& Leco TGA701 analyzer \& Leco AC 500 calorimeter). The chemical composition of feedstock was determined by standard Tappi procedure. The results of ultimate analysis, proximate analysis, HHV and compositional analysis with their standard deviations (SD) are described in Table 1. In which ash was the remains after complete combustion, volatile matter was volatilized fraction from maize stalk when it was heated in the absence of oxygen, fixed carbon was the leftovers after complete volatilization and higher heating value was the thermal energy comprised in the maize stalk.

GC-MS analyser (Shimadzu GC/MS-QP2010) was used to identify the chemical compounds present in the bio-oil. Composition of incondensable gas was obtained by GC analyser (Cp-3800/3300 Netherland). The oven ramp rate, hold up time and injector temperature details can be seen $a^{60}$.

\section{Experimental apparatus}

Bubbling fluidized bed fast pyrolysis system (Fig. 1) was used for the investigations under study. The fluidized bed reactor was made of stainless steel (SS 316 L) and had internal diameter of $100 \mathrm{~mm}$ with feed capacity of

Table 1. Characteristics of maize stalk

\begin{tabular}{|c|c|c|c|c|c|c|c|c|}
\hline \multicolumn{2}{|c|}{ Ultimate Analysis [wt\%] } & \multirow{2}{*}{$\begin{array}{c}\text { SD } \\
0.3\end{array}$} & \multicolumn{2}{|c|}{ Proximate Analysis [wt\%] } & \multirow{2}{*}{$\begin{array}{l}\text { SD } \\
0.4\end{array}$} & \multicolumn{2}{|c|}{ Chemical Composition [wt\%] } & \multirow{2}{*}{$\frac{\mathrm{SD}}{1.0}$} \\
\hline Carbon & 40.72 & & Volatile Matter & 62.94 & & Cellulose & 29.7 & \\
\hline Hydrogen & 5.68 & 0.1 & Fixed Carbon & 30.24 & 0.2 & Hemicelluloses & 15.2 & 0.5 \\
\hline Oxygen & 47.51 & 0.2 & Ash & 4.20 & 0.1 & Lignin & 17.2 & 0.9 \\
\hline Sulfur & 0.12 & 0.01 & $\mathrm{HHV}(\mathrm{MJ} / \mathrm{kg})$ & 15.87 & 0.2 & - & - & - \\
\hline
\end{tabular}


$2 \mathrm{~kg} / \mathrm{h}$. The reactor was heated indirectly with carbide heating rods to maintain the pyrolysis reaction temperature. More details of the experimental setup and its operational procedure can be seen $\mathrm{at}^{\mathbf{6 0}}$.

The maize stalk was pyrolysed in the fluidized bed reactor at temperature $360-540^{\circ} \mathrm{C}$ and yield of bio-oil, charcoal and incondensable gas were determined from condensed liquid collected from water and dry ice condensers, from two cyclones and by difference. These calculations were based on mass balance from the different components of pyrolysis system.

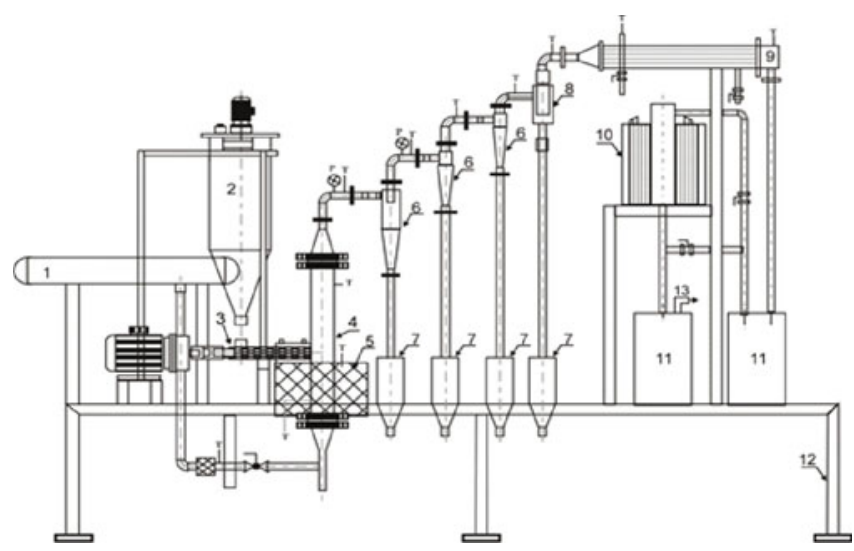

Figure 1. Schematic of experimental apparatus

1. Nitrogen Gas Header; 2. Feed Hopper; 3. Screw Feeder; 4. Fluidized Bed Reactor; 5. Reactor Heater; 6. Cyclone Separators; 7. Char Collectors; 8. Hot Filter; 9. Water Condenser; 10. Dry Ice Condenser; 11. Bio-oil Collectors; 12. Frame; 13. Exhaust Gas

\section{Reaction conditions}

The various reaction conditions for fast pyrolysis of maize stalk are shown in Table 2. The temperature from the exit of the reactor to inlet of condenser was maintained at $350-400^{\circ} \mathrm{C}$ in order to avoid condensation of pyrolysis vapors prior to the bio-oil formation.

\section{RESULTS AND DISCUSSION}

\section{Effect of temperature on products yield}

The effect of temperature on pyrolysis product distribution of maize stalk in the fluidized bed fast pyrolysis system is described in Figure 2. The rise of temperature from 360 to $540^{\circ} \mathrm{C}$, yield of char decreased while yield of gas increased. By the increase in the reaction temperature from 360 to $490^{\circ} \mathrm{C}$, the yield of bio-oil increased, even though at the considerable greater temperature of $540^{\circ} \mathrm{C}$, there was a drop in the yield of bio-oil. The value of bio-oil obtained was maximum $(42 \mathrm{wt} \%)$ at a pyrolysis temperature of $490^{\circ} \mathrm{C}$. These results lead that bio-oil and char decreased whereas gas increased with the increase of reaction temperature. The results were due to secondary cracking reactions by the conversion of pyrolysis vapors and char into gas at elevated temperatures. These trends of pyrolysis liquid, char and non-condensable gas yields with temperature were in agreement to the results in the literature ${ }^{\mathbf{6 1 - 6 5}}$. The yields obtained by Park et al. ${ }^{\mathbf{5 3}}$ $\&$ Asadullah et al. ${ }^{66}$ were $50,66 \%$ for fast pyrolysis of radiate pine sawdust and jute stick in fluidized bed reactor at $450^{\circ} \mathrm{C}$ and $500^{\circ} \mathrm{C}$ respectively. The difference in yields and composition of pyrolysis products identified was described due to the type of feedstock, reaction conditions, size of reactor and experimental errors. In large reactors, a significant fraction of tar was trapped in the pipes and lines of the fast pyrolysis reactor which reduced the yield of liquid product. This proportion of the product was very difficult to collect physically from the system.

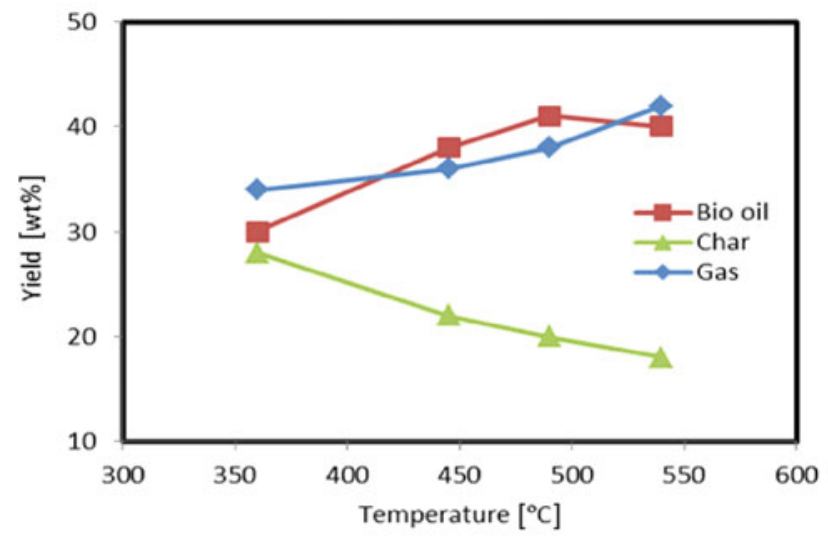

Figure 2. Effect of temperature on the yield of bio-oil, char and gas

\section{Effect of particle size on products yield}

Biomass particle size was found to influence the yield of pyrolysis products. With the increase of particle size, bio-oil yield decreased and char yield increased as these particles heat up more slowly ${ }^{\mathbf{3 6}}$. On the other hand, small particle size increased the gas yield as a result of greater heat transfer coefficient ${ }^{37}$. So distribution of the products yields strongly depend on the particle size, demanding a practically uniform temperature distribution inside the reactor. Moreover, particle size of biomass was especially reliant on the type of reactor used for fast pyrolysis. In continuous-feed fluidized bed reactors, small biomass particle sizes $(\leq 2 \mathrm{~mm})^{\mathbf{3}, 22}$ was agreed to achieve high heating rates. The small biomass particle size was required in order to get rapid heating and complete devolatilization in the pyrolysis process ${ }^{38,39}$.

Pyrolysis of maize stalk for feed sizes of 1.0, 1.5 and $2.0 \mathrm{~mm}$ is depicted in Figure 3 for pyrolysis products distribution. It was evident that yield of bio-oil was decreased with the rise of feed particle size and also visible that effect was linear over the selected range of particle sizes. It was shown from the graphs that the bio-oil yield was decreased by increasing the feed size of maize stalk whereas char and gas yields were increased. For maize stalk, the bio-oil yield decreased from 42 to $35 \mathrm{wt} \%$, char yield from 22 to $25 \mathrm{wt} \%$ increased and gas yield was increased from 36 to $40 \mathrm{wt} \%$ by the

Table 2. Reaction conditions

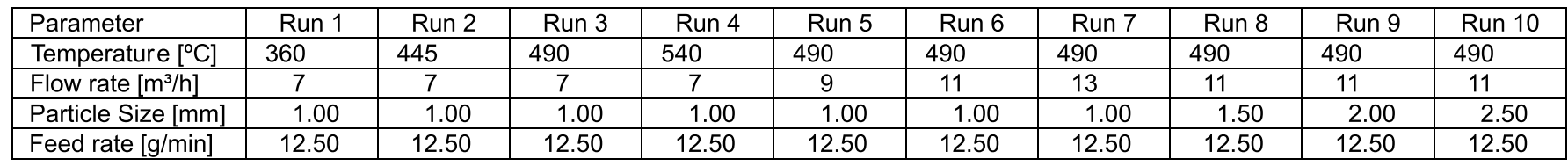


increase of particle size of feedstock. This effect of particle size of biomass during pyrolysis was conceived due to the heating rate. Heat transfer in the pyrolysis was related with the particle size of feed, greater the particle size, lower would be heat transfer and vice versa. The greater heat transfer in case of fine particles produced more volatiles which condensed consequently resulting in higher bio-oil yield. The trends in literature ${ }^{44,63,67}$ regarding the effect of feed particle size in pyrolysis favored these results.

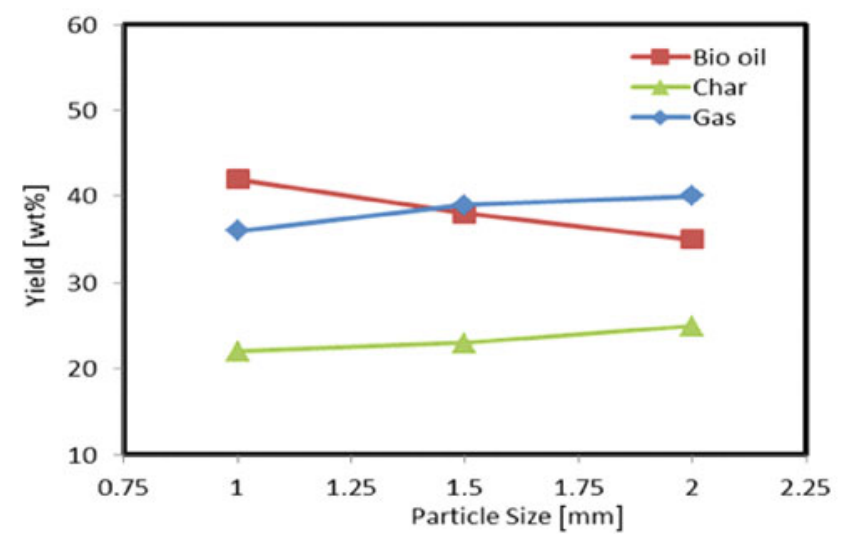

Figure 3. Effect of feed particle size on the yield of bio-oil, char and gas

\section{Effect of carrier gas flow rate on products yield}

The effect of carrier gas flow rate on pyrolysis product distribution of maize stalk is shown in Figure 4. It wass found that with the increase of gas flow rate, bio-oil yield was first increased and then decreased. The maximum amount of bio-oil obtained for maize stalk was $42 \mathrm{wt} \%$ at the carrier gas flow rate of $11.0 \mathrm{~m}^{3} / \mathrm{h}(0.9$ $\mathrm{m} / \mathrm{s}$ superficial velocity). The increase in carrier gas/ $\mathrm{N}_{2}$ gas flow rate decreased the yield of bio-char while the yield of gas was decreased first and then increased. This was for the reason that at low flow rate of carrier gas, fluidization was not completely attained and hence, fast pyrolysis could not occur fully ${ }^{68}$ and secondly, due to long vapor residence time, secondary reactions such as cracking and re-polymerization might take place. Conversely, the high flow rate of carrier gas decreased the bio-oil yield due to the reason that volatiles left the pyrolysis system without effective condensation and results in gas formation.

The carrier gas flow affects the residence time of the vapors produced by pyrolysis reactions which removes the pyrolysis products from the reactor hot zone immediately and minimizes the secondary cracking vapor reactions ${ }^{69}$. It is known that pyrolysis process conversion is increased in minor amounts and influence on yield of char with increasing the flow rate of nitrogen/carrier gas is insignificant. By increasing the carrier gas flow rate, there is an increase in the bubbling motion which enhances the mixing between bed material and biomass. Ultimately, vapor residence time is decreased lowering the secondary reactions. But at higher carrier gas flow rate, bubbling of the sand bed starts vigorously which reduces the solid mixing and gives low heat transfer decreasing the pyrolysis oil yield.

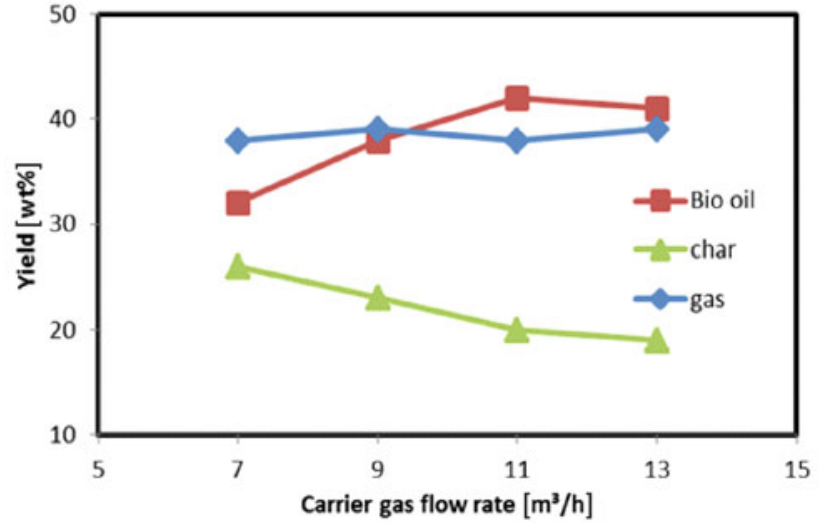

Figure 4. Effect of carrier gas flow rate on the yield of bio-oil, char and gas

\section{Characterization of Bio-Oil}

The bio-oil consists of water and organic compounds which were condensed and collected after pyrolysis experiments. The liquid oil was characterized by measuring the density, viscosity, water content, acid number and calorific value. The amount of water in the bio-oil was determined by Karl Fischer titrator which was based on the theory of Karl Fischer titration. The chemical composition of bio-oil was analysed with gas chromatography-mass spectroscopy (GC-MS). The properties and chemical composition of bio-oil is elaborated in Tables 3 and 4 respectively.

Table 3. Properties of bio-oil

\begin{tabular}{|l|c|}
\hline Properties & Value \\
\hline $\mathrm{H}_{2} \mathrm{O}[\mathrm{wt} \%]$ & 32.4 \\
\hline TAN $[\mathrm{mg}$ of $\mathrm{KOH} / \mathrm{g}]$ & 74 \\
\hline Density $\left[\mathrm{g} / \mathrm{m}^{3}\right]$ & 1150 \\
\hline Viscosity $\left[\mathrm{cP} @ 20^{\circ} \mathrm{C}\right]$ & 104 \\
\hline $\mathrm{HHV}[\mathrm{MJ} / \mathrm{kg}]$ & 17.8 \\
\hline $\mathrm{C}[\mathrm{wt} \%]$ & 48.6 \\
\hline $\mathrm{H}[\mathrm{wt} \%]$ & 6.4 \\
\hline $\mathrm{O}[\mathrm{wt} \%]$ & 43.9 \\
\hline $\mathrm{N}[\mathrm{wt} \%]$ & 0.9 \\
\hline $\mathrm{S}[\mathrm{wt} \%]$ & 0.2 \\
\hline
\end{tabular}

Table 3 shows that energy density of bio-oil was much higher than the feedstock which made it convenient for transportation and utilization. Also liquid product contained small fractions of nitrogen and sulfur which were pollutants. The results of elemental analysis indicated that carbon and hydrogen content was increased as compared with the feedstock and like this oxygen decreased. Due to increase in carbon content and drop in oxygen content, the calorific value was also increased. The similar results were observed by Putun et al. ${ }^{70}$ for pyrolysis of pistachio shell in fluidized bed reactor.

GC-MS analysis was applied to separate and identify the chemical compounds in bio-oil. The chemical compounds were identified from the GC-MS peaks of chromatogram (Fig. 5) by comparison with the spectra of spectrum library. The compounds identified in liquid product from maize stalk pyrolysis in fluidized bed reactor were large in numbers having major and minor concentrations in area percentage but only compounds with major fractions are mentioned in the Table 4. The compounds were acetic acid, aldehydes, ketones, phenols and anhydrosugars. The concentration of acetic acid was 
higher than phenols, furfural, furanone and levoglucosan. The results of GC-MS having chemical composition of liquid oil were in agreement with the results by Zheng ${ }^{71}$ for rice husk feedstock in fluidized bed reactor.

It could be observed from the qualitative results that acidic acid is the major acidic components of bio-oil, furfural is the furans product and 1-hydroxy-2-propanone, cyclopentanones and cyclopentadiones are the ketones. Levoglucosan is obtained from cellulose pyrolysis and indicates the partial cracking of carbohydrates. The compounds such as 2-methoxy-phenol, 2-methoxy-4-methyl-phenol are methylated or methoxylated phenolic compounds derived from lignin pyrolysis. The compounds in bio-oil were acids, ketones, phenols, furans followed by anhydrosugars, whereas alcohols, aldehydes and esters were present in small fractions. The major organic acid was acetic acid holding the highest part. Bio-oil had the highest acetic acid content of 27 area \%. It has been known that acetic acid was produced mainly due to the breakage and removal of acetyl groups linked to the xylose unit on C-2 position and second attributed to the ring-scission of uronic acid residues from elimination of groups such as carbonyl and O-methyl ${ }^{72}$. The amount of acetic acid content of bio-oil would vary due to different chemical structure and content.

Maize stalk pyrolysis produced a large amount of ketones of which total amount was around 18-20 area $\%$ with 1-hydroxy-2-propanone highest yield up to 16.38 area $\%$. The large molecular weight ketones such as cyclopentanones and cyclopentenones were produced from the degradation of sugar units. The ketones were produced from the pyrolysis of cellulose or hemicellulose of biomass. Furans in the bio-oil can be yielded from the decomposition of hollocellulose, even though both cellulose and hemicellulose can produce furans, however studies has revealed that hemicellulose contributes to the formation of furfural and cellulose to hydroxymethyl furfural and 2-furylmethanol ${ }^{\mathbf{7 3}, 74}$. Bio-oil from maize stalk pyrolysis has furfural content about 2.31 area $\%$ due to hemicellulose content lower than cellulose and lignin in the feedstock. The anhydrosugar compounds were levoglucosan and its dehydration or isomeric forms and produced from degradation of cellulose. The yield of levoglucosan in the bio-oil was 2.36 area \% depending upon the amount of cellulose in the feedstock. The quantitative chemical characterization of bio-oil is valuable in order to design the pyrolysis reaction and estimation of economic significance of practical applications like fuels and chemicals. The bio-oil is composed of mainly, water, acetic acid (27 area \%), 1-hydoxy-2-propanone (16 area \%) and small fraction of other compounds $(<4$ area \%) such as phenols, aldehydes and levoglucosan.

Bio-oil contains about $32 \mathrm{wt} \%$ of water which generally originates from initial moisture in the biomass and dehydration reactions taking place during pyrolysis process. Water content may be different due to nature of feedstock and process conditions. Water at high concentration $(15-30 \%)$ is miscible with the oligomeric components derived from lignin due to solubilizing effect of low-molecular-weight acids, alcohols, hydroxyaldehydes, and ketones resulting from the decomposition of carbohydrates. Water in the bio-oil has both negative as well as positive effects on the oil properties. It decreases the heating value and flame temperature and increases the delay in ignition. In contrast, it reduces the viscosity of bio-oil resulting in increase of flow characteristics which has advantage for pumping and atomization in combustion.

In the past, pyrolysis liquids from wood were used to produce chemicals like methanol, acetic acid, turpentine and tars etc. but presently these chemicals are formed from other feed stocks derived from natural gas, crude oil and coal at cheaper cost. The bio-oils have been comprised of more than 200 chemical compounds present in small parts and separation of individual compounds is often practical as well as economic due to complex separation techniques. Thus, producing valuable chemicals from the whole bio-oil or easily separable major fraction is viable and economical. The suitable chemicals can be produced from the whole bio-oil by reacting most abundant functional groups as carbonyl, carboxyl and phenolic in such a way that non reacting part of bio-oil would not be separated from the product. Bio-oil containing acetic acid and phenols has carboxyl and phenolic groups which can easily react with lime to yield calcium salts and phenates. The product obtained is termed as BioLime which can be used to capture $\mathrm{SO}_{\mathrm{x}}$ emissions from coal combustors in the industry. BioLime contains about $50 \%$ water and $7-14 \%$ organic calcium which is four times more efficient for capturing acid gas. The second advantage of BioLime is its oxidation of organic bio-oil derived part resulting in additional energy in the combustor. Based on this principal Dynamotive Corporation $^{75}$ has developed the same product which ascertained effective.

Bio-oil exploits another potential application due to high amount of carbonyl groups such as 1-hydroxy 2-propanone, acetic acids and aldehydes. Various imide and amide bonds are produced between carbonyl carbon and nitrogen from reaction of bio-oil with ammonia, urea and $-\mathrm{NH}_{2}$ containing materials. In this method, biodegradable slow releasing fertilizer with $10 \%$ nitrogen is produced which has lower leachability in comparison to mineral fertilizers producing less pollution to ground water. Moreover, it is good soil conditioning material having humic material (lignin) and use of such type of fertilizer returns carbon to soil and revealed as a method of carbon sequestration. Bio-oil based fertilizers ${ }^{76}$ may be cost competitive in the market.

In addition, various chemicals can be produced from fractionation of bio-oil. Bio-oil can be easily fractionated into two parts on basis of water solubility, an oligomeric lignin derived fraction settles down whereas water soluble fraction containing carbohydrate derived compounds arises as top layer. Solvent fractionation methods other than water have also been developed, however water addition method is most economical option $^{77}$. Water soluble fraction of bio-oil comprising organic acids (acetic acids, formic acids \& propionic acids) has a prospective application of production of calcium salts of carboxylic acids. The calcium salts of carboxylic acids can be used as environment friendly road de-icers. The aqueous extract of bio-oil rich in organic acids can be distilled off as sub fraction. This fraction consisting of other volatile compounds such as 
aldehydes and esters can react with lime or evaporated in the recovery of calcium salts. The production of biomass derived de-icers is viable. The water insoluble fraction of bio-oil composed of oligomeric fragments is known as pyrolytic lignin can be used as phenol substitute in phenol-formaldehyde resins. Those resins presenting high mechanical strength are effectively used as adhesives in plywood and particle board industry. In comparison to phenol, pyrolytic lignin is an attractive component of adhesives due to low toxicity and cost. NREL ${ }^{78}$ and Biocarbons $^{79}$ in USA has leading contributions in the pyrolytic lignin based resin formulation.

Furthermore to above applications of bio-oil, terpenoid and phenolic compounds present in the bio-oil were identified as insecticides and fungicides which proposed it to be used as wood preservative. Impregnating with bio-oil shields the wood from fungi, conversely efficiency of bio-oil was not found long lasting. After the improve-

Figure 5. GC-MS Chromatogram of bio-oil
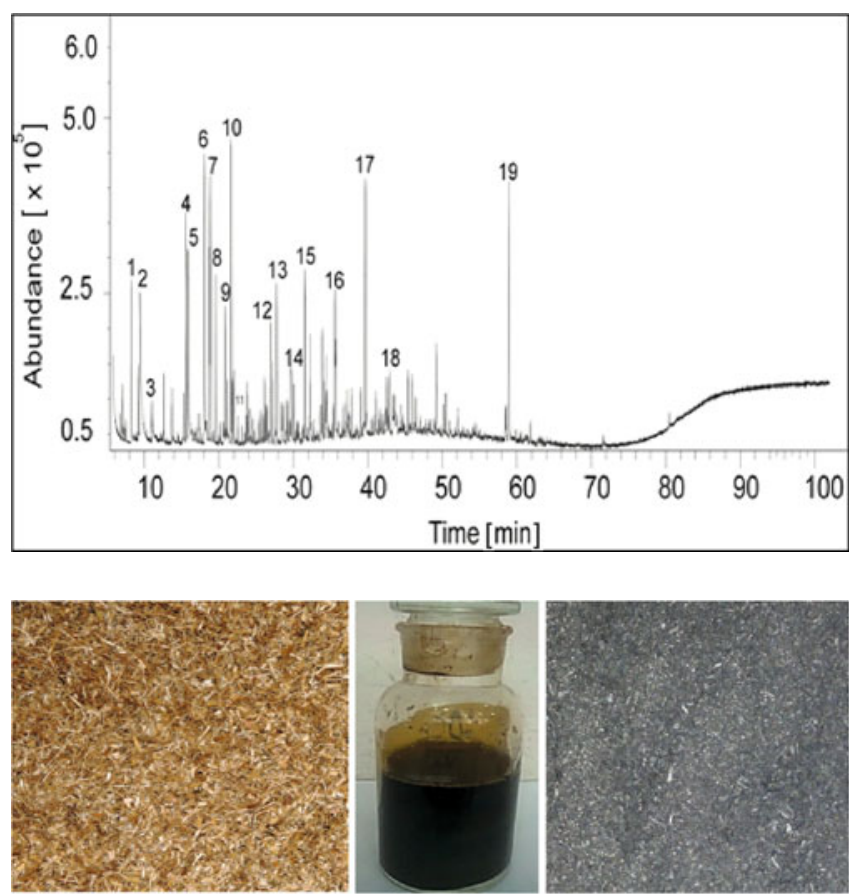

(a)

(b)

(c) ment of retention of bio-oil in the wood, it can be used as environment friendly wood preservative.

Figure 6 represents the feedstock (maize stalk) and pyrolysis products (bio-oil, char) respectively.

\section{CONCLUSIONS}

Fast pyrolysis of maize stalk was investigated in locally designed and fabricated fluidized bed reactor. The effect of operating parameters such as pyrolysis temperature, feed particle size and carrier gas flow rate was studied. It was observed from the experiments that reaction temperature had significant influence on the distribution of pyrolysis products. The yield of bio-oil was increased with the temperature to maximum upto a certain temperature and then decreased by the increase of temperature while yield of char decreased and gas increased. In addition to pyrolysis temperature, feed particle size also affects the yields of fast pyrolysis process. The bio-oil yield was decreased by the increase of particle size and yields of bio-char \& gas increased. The maximum yield of bio-oil obtained was $42 \mathrm{wt} \%$ at the optimum pyrolysis temperature of $490^{\circ} \mathrm{C}$, feed size of $1.0 \mathrm{~mm}$ and carrier gas flow rate of $11 \mathrm{~m}^{3} / \mathrm{h}$. The major compounds found in the bio-oil obtained from the pyrolysis of maize stalk were acetic acid, 1-hydroxy-2-propanone,2.3-dihydro-benzofuran, phenols,3-methyl-1.2-cyclopentanedione, 1-(acetyloxy)-2-propanone, 2.3-dimethyl-cyclopenten-1-one, furfural, 2(5H)-furanone and levoglucosan.

\section{ACKNOWLEDGEMENT}

Financial support of the Higher Education Commission (Project \# 20-1701/R \& D/09/2946) and University of the Punjab, Pakistan for this research work is highly acknowledged.

Figure 6. (a) Maize stalk, (b) Bio-oil, (c) Char

Table 4. GC-MS analysis of bio-oil

\begin{tabular}{|l|c|l|c|}
\hline Peak \# & RT [min] & \multicolumn{1}{c|}{ Compound } & Area [\%] \\
\hline 1 & 8.15 & 2-amino-1.3-propanediol & 1.47 \\
\hline 2 & 9.39 & acetic acid & 27.35 \\
\hline 3 & 10.97 & 1-hydroxy-2-propanone & 16.38 \\
\hline 4 & 15.61 & 1-hydroxy-2-butanone & 1.84 \\
\hline 5 & 15.85 & acetic acid, methyl ester & 3.67 \\
\hline 6 & 18.06 & butanedial & 2.52 \\
\hline 7 & 18.75 & 2-cyclopenten-1-one & 1.69 \\
\hline 8 & 18.85 & furfural & 2.31 \\
\hline 9 & 20.85 & 2.2 .4 -trimethyl-1.3-dioxolane & 1.54 \\
\hline 10 & 21.67 & 1-(acetyloxy)-2-propanone & 2.67 \\
\hline 11 & 22.03 & 2-butanone & 1.18 \\
\hline 12 & 26.93 & 2.3 -dimethyl-cyclopenten-1-one & 1.24 \\
\hline 13 & 27.77 & 2(5H)-furanone & 1.13 \\
\hline 14 & 29.76 & 3-methyl-1.2-cyclopentanedione & 3.04 \\
\hline 15 & 31.55 & phenol & 3.09 \\
\hline 16 & 35.70 & 4-methyl-phenol & 1.27 \\
\hline 17 & 39.69 & 4-ethyl-phenol & 2.15 \\
\hline 18 & 43.62 & 2.3-dihydro-benzofuran & 3.66 \\
\hline 19 & 58.97 & levoglucosan & 2.36 \\
\hline
\end{tabular}




\section{LITERATURE CITED}

1. Goyal, H.B., Seal, D. \& Saxena, R.C. (2008). Bio-fuels from thermochemical conversion of renewable resources: a review. Renew. Sust. Ener. Rev. 12, 504-517. DOI: 10.1016/j. rser.2006.07.014.

2. Raheem, A., Azlina, W.W., Yap, Y.H.T., Danquah, M.K. \& Harun, R. (2015). Thermochemical conversion of microalgal biomass for biofuel production. Renew. Sust. Ener. Rev. 49, 990-999. DOI: 10.1016/j.rser.2015.04.186.

3. Bridgwater, A.V. \& Peacocke, G.V.C. (2000). Fast pyrolysis processes for biomass. Renew. Sust. Ener. Rev. 4, 1-73. DOI: 10.1016/S1364-0321(99)00007-6.

4. Yaman, S. (2004). Pyrolysis of biomass to produce fuels and chemical feedstocks. Ener. Conv. Manage. 45, 651-671. DOI: 10.1016/S0196-8904(03)00177-8.

5. Goyal HB, S.R. \& Seal, D. Communicated to Haworth Press, USA, 2006. (2006). Thermochemical Conversion of Biomass To Liquids and Gas, Monograph. DOI: 10.1016/j. rser.2006.07.014.

6. Bridgwater, A.V. (1999). Principles and practice of biomass fast pyrolysis processes for liquids. J. Anal. Appl. Pyrol. 51, 3-22. DOI: 10.1016/S0165-2370(99)00005-4.

7. Bridgwater, A.V. Review of fast pyrolysis of biomass and product upgrading. Biom. Bioener. 38, 68-94. DOI: 10.1016/j. biombioe.2011.01.048.

8. Mohan, D., Pittman, C.U. \& Steele, P.H. (2006). Pyrolysis of wood/biomass for bio-oil: a critical review. Energy \& Fuels 20, 848-889. DOI: 10.1021/ef0502397.

9. Babu, B.V. (2008). Biomass pyrolysis: a state of art review. Biof. Bioprod. Bioref. 2, 393-414. DOI: 10.1002/bbb.92.

10. Bridgewater, A.V. (2004). Biomass fast pyrolysis. Ther. Sci. 8, 21-50. DOI: 10.2298/TSC10402021B.

11. Bimbella, F., Abrego, J., Gonzalo, A., Sanchez, J.L. \& Arauzo, J. (2014). Biomass pyrolysis liquids. Fundamentals, technologies and new strategies. Bol. Grup. Esp. Carb. DOI: 10261/108782.

12. Jahirul, M.I., Rasul, M.G., Chowdhury, A.A. \& Ashwath, N. (2012). Biofuels production through biomass pyrolysis, a technological review. Energies 5, 4952-5001. DOI: 3390/ en5124952.

13. Demirbas, A. \& Arin, G.N. (2002). An overview of biomass pyrolysis. Ener. Sour. 24, 471-482. DOI: 10.1080/00908310252889979.

14. Akhtar, J. \& Amin, N.A.S. (2011). A review on process conditions for optimum bio-oil yield in hydrothermal liquefaction of biomass. Renew. Sust. Ener. Reviews. 15, 1615-1624. http://dx.doi.org/10.1016/j.rser.2010.11.054

15. Balat, M., Balat, M., Kirtay, E. \& Balat, H. (2009). Main routes for the thermo-conversion of biomass into fuels and chemicals. Part 1: Pyrolysis systems. Ener. Con. Managem. 50, 3147-3157. DOI: 10.1016/j.enconman.2009.08.014.

16. Zabaniotou, A.A., Roussos, A.I. \& Koroneos, C.J. (2000). A laboratory study of cotton gin waste pyrolysis. J. Anal. Appl. Pyrol. 56, 47-59.

17. Abdullah, N. \& Bridgwater, A.V. (2006). Pyrolysis liquid derived from oil palm empty fruit bunches. J. Phys. Sci. 17, 117-129. DOI: 10.1016/S0165-2370(00)00088-7.

18. Putun, A.E., Uzbay, N., Apaydin Varol, E., Uzun, B. B. \& Ates, F. (2007). Rapid and slow pyrolysis of pistachio shell: effect of pyrolysis conditions on the product yields and characterization of the liquid product. Inter. J. Ener. Res. 31, 506-514. DOI: 10.1002/er.1263.

19. Akhtar, J. \& Saidina Amin, N. A review on operating parameters for optimum liquid oil yield in biomass pyrolysis. Renew. Sustain. Ener. Rev. 16, 5101-5109. DOI: 10.1016/j. rser.2012.05.033.

20. Shafizadeh, F. (1982). Introduction to pyrolysis of biomass. J. Anal. Appl. Pyrol. 3, 283-305. DOI: 10.1016/01652370(82)80017-X.
21. Scott, D.S., Piskorz, J., Bergougnou, M.A., Graham, R. \& Overend, R.P. (1988). The role of temperature in the fast pyrolysis of cellulose and wood. Indust. \& Engine. Chem. Res. 27, 8-15. DOI: 10.1021/ie00073a003.

22. Bridgwater, A.V. (2003). Renewable fuels and chemicals by thermal processing of biomass. Chem. Engine. J. 91, 87-102. DOI: $10.1016 / \mathrm{S} 1385-8947(02) 00142-0$.

23. Bridgwater, A.V., Meier, D. \& Radlein, D. (1999). An overview of fast pyrolysis of biomass. Org. Geochem. 30, 1479-1493. DOI: 10.1016/S0146-6380(99)00120-59.

24. Piskorz, J., Majerski, P., Radlein, D., Scott, D.S. \& Bridgwater, A.V. (1998). Fast pyrolysis of sweet sorghum and sweet sorghum bagasse. J. Anal. Appl. Pyrol. 46, 15-29. DOI: 10.1016/S0165-2370(98)00067-9.

25. Horne, P.A. \& Williams, P.T. (1996). Influence of temperature on the products from the flash pyrolysis of biomass. Fuel. 75, 1051-1059. DOI: 10.1016/0016-2361(96)00081-6.

26. Demirbas, A. (2007). The influence of temperature on the yields of compounds existing in bio-oils obtained from biomass samples via pyrolysis. Fuel Proces. Technol. 88, 591-597. DOI: 10.1016/j.fuproc.2007.01.010.

27. Toft, A.J. (1996). A comparison of integrated biomass to electricity systems, Aston University.

28. Antal, M.J. \& Gronali, M. (2003). The art, science, and technology of charcoal production. Indust. \& Engine. Chem. Res. 42, 1619-1640. DOI: 10.1021/ie0207919.

29. Onay, O. (2007). Influence of pyrolysis temperature and heating rate on the production of bio-oil and char from safflower seed by pyrolysis, using a well-swept fixed-bed reactor. Fuel Proces. Technol. 88, 523-531. DOI: 10.1016/j.fuproc.2007.01.001.

30. Bridgwater, A.V. (1999). Principles and practice of biomass fast pyrolysis processes for liquids. J. Anal. Appl. Pyrol. 51, 3-22. DOI: 10.1016/S0165-2370(99)00005-4.

31. Westerhof, R.J.M., Brilman, D.W.F., van Swaaij, W.P.M. \& Kersten, S.R.A. (2009). Effect of temperature in fluidized bed fast pyrolysis of biomass: oil quality assessment in test units. Indus. \& Engine. Chem. Res. 49, 1160-1168. DOI: 10.1021/ie900885c

32. Heo, H.S., Park, H.J., Yim, J.H., Sohn, J.M., Park, J., Kim, S.S., Ryu, C., Jeon, J.K. \& Park, Y.K. (2010). Influence of operation variables on fast pyrolysis of Miscanthus sinensis var. purpurascens. Biores. Technol. 101, 3672-3677. DOI: 10.1016/j.biortech.2009.12.078.

33. Pattiya, A. \& Suttibak, S. (2012). Production of bio-oil via fast pyrolysis of agricultural residues from cassava plantations in a fluidised-bed reactor with a hot vapour filtration unit. $J$. Anal. Appl. Pyrol. 95, 227-235. DOI: 10.1016/j.jaap.2012.02.010.

34. Mourant, D., Lievens, C., Gunawan, R., Wang, Y., Hu, X., Wu, L., Syed-Hassan, S.S.A. \& Li, C.Z. (2013). Effects of temperature on the yields and properties of bio-oil from the fast pyrolysis of mallee bark. Fuel. 108, 400-408. DOI: 10.1016/j.fuel.2012.12.018.

35. Antal, M.J. \& Gronli, M. (2003). The art, science, and technology of charcoal production. Indust. \& Engine. Chem. Res. 42, 1619-1640. DOI: 10.1021/ie0207919.

36. Park, H.J., Park, Y.K., Dong, J.I., Kim, J.S., Jeon, J.K., Kim, S.S., Kim, J., Song, B., Park, J. \& Lee, K.J. (2009). Pyrolysis characteristics of Oriental white oak: kinetic study and fast pyrolysis in a fluidized bed with an improved reaction system. Fuel Proces. Technol. 90, 186-195. DOI: 10.1016/j. fuproc.2008.08.017.

37. Nurul Islam, M., Zailani, R. \& Nasir Ani, F. (1999). Pyrolytic oil from fluidised bed pyrolysis of oil palm shell and itscharacterisation. Renew. Ener. 17, 73-84. DOI: 10.1016/ S0960-1481(98)00112-8.

38. Bridgwater, A.V. (2007). The production of biofuels and renewable chemicals by fast pyrolysis of biomass. Inter. J. Glob. Ener. Iss. 27, 160-203. DOI: 10.1504/IJGEI.2007.013654.

39. Huber, G.W., Iborra, S. \& Corma, A. (2006). Synthesis of transportation fuels from biomass: chemistry, catalysts, 
and engineering. Chem. Rev. 106, 4044-4098. DOI: 10.1021/ cr068360d.

40. Shen, J., Wang, X.S., Garcia-Perez, M., Mourant, D., Rhodes, M.J. \& Li, C.Z. (2009). Effects of particle size on the fast pyrolysis of oil mallee woody biomass. Fuel 88, 1810-1817. DOI: 10.1016/j.fuel.2009.05.001.

41. Scott, D.S. \& Piskorz, J. (1982). The flash pyrolysis of aspen poplar wood. Can. J. Chem. Engine. 60, 666-674. DOI: $10.1002 /$ cjce. 5450600514.

42. Raja, S.A., Kennedy, Z.R., Pillai, B.C. \& Lee, C.L.R. (2010). Flash pyrolysis of jatropha oil cake in electrically heated fluidized bed reactor. Energy 35, 2819-2823. DOI: 10.1016/j. energy.2010.03.011.

43. Heidari, A., Stahl, R., Younesi, H., Rashidi, A., Troeger, N. \& Ghoreyshi, A.A. (2014). Effect of process conditions on product yield and composition of fast pyrolysis of Eucalyptus grandis in fluidized bed reactor. J. Ind. Engine. Chem. 20, 2594-2602. DOI: 10.1016/j.jiec.2013.10.046.

44. Park, H.J., Dong, J.I., Jeon, J.K., Park, Y.K., Yoo, K.S., Kim, S.S., Kim, J. \& Kim, S. (2008). Effects of the operating parameters on the production of bio-oil in the fast pyrolysis of Japanese larch. Chem. Engine. J. 143, 124-132. DOI: 10.1016/j. cej.2007.12.031.

45. Choi, H.S., Choi, Y.S. \& Park, H.C. (2012). Fast pyrolysis characteristics of lignocellulosic biomass with varying reaction conditions. Renew. Ener. 42, 131-135. DOI: 10.1016/j. renene.2011.08.049.

46. Garcia-Perez, M., Wang, X.S., Shen, J., Rhodes, M.J., Tian, F., Lee, W.J., Wu, H. \& Li, C.Z. (2008). Fast pyrolysis of oil mallee woody biomass: effect of temperature on the yield and quality of pyrolysis products. Ind. \& Engine. Chem. Res. 47, 1846-1854. DOI: 10.1021/ie071497p.

47. Putun, E., Uzun, B.B. \& Putun, A.E. (2006). Fixed-bed catalytic pyrolysis of cotton-seed cake: effects of pyrolysis temperature, natural zeolite content and sweeping gas flow rate. Biores. Technol. 97, 701-710. DOI:10.1016/j.biortech.2005.04.005.

48. Bridgwater, A.V. (2012). Review of fast pyrolysis of biomass and product upgrading. Biom. Bioener. 38, 68-94. DOI: 10.1016/j.biombioe.2011.01.048

49. Bridgwater, T. (2006). Biomass for energy. J. Sci. Food Agric. 86, 1755-1768. DOI: 10.1002/jsfa.2605.

50. Hoekstra, E., Hogendoorn, K.J.A., Wang, X., Westerhof, R.J.M., Kersten, S.R.A., van Swaaij, W.P.M. \& Groeneveld, M.J. (2009). Fast pyrolysis of biomass in a fluidized bed reactor: in situ filtering of the vapors. Ind. \& Engine. Chem. Res. 48, 4744-4756. DOI: 10.1021/ie8017274.

51. Uzun, B.B., Putun, A.A. \& Putun, E. (2006). Fast pyrolysis of soybean cake: product yields and compositions. Biores. Technol. 97, 569-576. DOI: 10.1016/j.biortech.2005.03.026.

52. Bridgwater, A.V. (1997) Biomass fast pyrolysis and applications in Europe. In Making a Business from Biomass in Energy, Environment, Chemicals, Fibers, and Materials. Proc. Third Biomass Conf. of the Americas, Vols, pp. 797-809.

53. Park, H.J., Park, Y.K. \& Kim, J.S. (2008). Influence of reaction conditions and the char separation system on the production of bio-oil from radiata pine sawdust by fast pyrolysis. Fuel Proces. Technol. 89, 797-802. DOI: 10.1016/j. fuproc.2008.01.003.

54. Scott, D.S., Majerski, P., Piskorz, J. \& Radlein, D. (1999). A second look at fast pyrolysis of biomass-the RTI process. J. Anal. Appl. Pyrol. 51, 23-37. DOI: 10.1016/S01652370(99)00006-6.

55. Heo, H.S., Park, H.J., Park, Y.K., Ryu, C., Suh, D.J., Suh, Y.W., Yim, J.H. \& Kim, S.S. (2010). Bio-oil production from fast pyrolysis of waste furniture sawdust in a fluidized bed. Biores. Technol. 101, S91-S96. DOI: 10.1016/j.biortech.2009.06.003.

56. Raja, S., Smart, A., Robinson, D.S., Pillai, B.C., Robert, L. \& Lindon, C. (2011). Parametric studies on Pyrolysis of pungam oil cake in electrically heated fluidized bed research reactor. Res. J. Chem. Sci. 1, 70-80.
57. Sulaiman, F. \& Abdullah, N. (2011). Optimum conditions for maximising pyrolysis liquids of oil palm empty fruit bunches. Energy 36, 2352-2359. DOI: 10.1016/j.energy.2010.12.067.

58. Mante, O.D. \& Agblevor, F.A. (2011). Parametric study on the pyrolysis of manure and wood shavings. Biom. Bioener. 35, 4417-4425. DOI: 10.1016/j.biombioe.2011.08.017.

59. Tsai, W.T., Lee, M.K. \& Chang, Y.M. (2007). Fast pyrolysis of rice husk: product yields and compositions. Biores.Technol. 98, 22-28. DOI: 10.1016/j.biortech.2005.12.005.

60. Ali, N., Saleem, M., Shahzad, K. \& Chughtai, A. (2015). Bio-Oil Production from Fast Pyrolysis of Cotton Stalk in Fluidized Bed Reactor. Ara. J. Sci. Engine. 40, 3019-3027. DOI: 10.1007/s13369-015-1801-z.

61. Zheng, J.L. (2008). Pyrolysis oil from fast pyrolysis of maize stalk. J. Anal. Appl. Pyrol. 83, 205-212. DOI: 10.1016/j. jaap.2008.08.005.

62. Xueyuan, B., Weiming, Y., Lihong, W., Yongjun, L. \& Hongzhen, C. (2005). Fast pyrolysis of corn stalk for bio-oil in a plasma heated fluidized bed. Trans. Chin. Soc. Agric. Engine. 21, 127-130.

63. Park, H.J., Park, Y.K. \& Kim, J.S. (2008). Influence of reaction conditions and the char separation system on the production of bio-oil from radiata pine sawdust by fast pyrolysis. Fuel Proces. Technol. 89, 797-802. DOI: 10.1016/j. fuproc.2008.01.003.

64. Wang, X., Kersten, S.R.A., Prins, W. \& van Swaaij, W.P.M. (2005). Biomass pyrolysis in a fluidized bed reactor. Part 2: Experimental validation of model results. Ind. \& Engine. Chem. Res. 44, 8786-8795. DOI: 10.1021/ie050486y.

65. Garcia-Perez, M., Chaala, A., Pakdel, H., Kretschmer, D. \& Roy, C. (2007). Characterization of bio-oils in chemical families. Biom. Bioener. 31, 222-242. DOI: 10.1016/j.biombioe.2006.02.006.

66. Asadullah, M., Rahman, M.A., Ali, M.M., Motin, M.A., Sultan, M.B., Alam, M.R. \& Rahman, M.S. (2008). Jute stick pyrolysis for bio-oil production in fluidized bed reactor. Biores. Technol. 99, 44-50.

67. Kim, S.J., Jung, S.H. \& Kim, J.S. Fast pyrolysis of palm kernel shells: influence of operation parameters on the bio-oil yield and the yield of phenol and phenolic compounds. Biores. Technol. 101, 9294-9300. DOI: 10.1016/j.biortech.2010.06.110.

68. Islam, M.N., Zailani, R. \& Ani, F.N. (1999). Pyrolytic oil from fluidised bed pyrolysis of oil palm shell and itscharacterisation. Ren. Ener. 17, 73-84. DOI: 10.1016/S0960-1481(98)00112-8.

69. Encinar, J.M., Gonzalez, J.F. \& Gonzalez, J. (2000). Fixed-bed pyrolysis of Cynara cardunculus L. Product yields and compositions. Fuel Proc. Technol. 68, 209-222. DOI: 10.1016/ S0378-3820(00)00125-9.

70. Putun, A.E., Ozbay, N., Apaydin Varol, E., Uzun, B. B. \& Ates, F. (2007). Rapid and slow pyrolysis of pistachio shell: effect of pyrolysis conditions on the product yields and characterization of the liquid product. Inter. J. Ener. Res. 31, 506-514. DOI: 10.1002/er.1263.

71. Ji-Lu, Z. (2007). Bio-oil from fast pyrolysis of rice husk: Yields and related properties and improvement of the pyrolysis system. J. Anal. Appl. Pyrol. 80, 30-35. DOI: 10.1016/j. jaap.2006.12.030.

72. Lv, G.J., Wu, S.B. \& Lou, R. (2010). Characteristics of corn stalk hemicellulose pyrolysis in a tubular reactor. BioRes. 5, 2051-2062.

73. Wang, S., Guo, X., Wang, K. \& Luo, Z. (2011). Influence of the interaction of components on the pyrolysis behavior of biomass. J. Anal. Appl. Pyrol. 91, 183-189. DOI: 10.1016/j. jaap.2011.02.006.

74. Lv, G., Wu, S., Yang, G., Chen, J., Liu, Y. \& Kong, F. (2013). Comparative study of pyrolysis behaviors of corn stalk and its three components. J. Anal. Appl. Pyrol. 104, 185-193. DOI: 10.1016/j.jaap.2013.08.005.

75. Zhou, J., Oehr, K., Simons, G. \& Barrass, G. (1997). Simultaneous NOx and SOx control using BioLime. Biomass 
Gasification and Pyrolysis, State of the Art and Future Prospects. CPL-Press. Newbury. S, 490-494.

76. Bridgwater, A.V. (2000). Slow release fertilizers by pyrolytic recycling of agricultural wastes. PyNe Newsletter. 10.

77. Chum, H.L. \& Black, S.K. (1990) Process for fractionating fast-pyrolysis oils, and products derived therefrom, Google Patents.

78. Chum, H.L. \& Kreibich, R.E. (1992) Process for preparing phenolic formaldehyde resole resin products derived from fractionated fast-pyrolysis oils, Google Patents.

79. Himmelblau, A. (1991) Method and apparatus for producing water-soluble resin and resin product made by that method, Google Patents. 